\title{
Whiter Shade of Pale: Making the Case for Jewish Presence in the Multicultural Classroom
}

\author{
Daniel lan Rubin \\ Jacksonville State University \\ U. S. A.
}

ABSTRACT: Despite over 4,000 years of persecution, American Jews and antisemitism continue to be overlooked in university multicultural and social justice classroom discussions. This is due to many factors, such as the misconceptions that Jews are solely a religious group, are White and have completely assimilated into American culture, and are economically successful. Jews are a distinctive group in the United States who continue to experience racism and oppression. In order to validate the racism and discrimination of Jews in the United States, university multicultural and social justice programs must begin to discuss the issues pertaining to antisemitism.

KEYWORDS: antisemitism, Whiteness, multicultural education, higher education, Judaism

\author{
Diversity and Multicultural Education \\ Antisemitism Statistics \\ The Notion of "Whiteness" and White Identity \\ Jewish Sense of Self \\ Exclusion from Multicultural and Social Justice Discourse \\ Conclusion \\ Notes \\ References \\ Author Contact
}

"White" or "Other," I asked myself recently while completing an online survey for an assistant professor position at a national university in the United States. I must have filled out at least 50 of these voluntary self-identification forms over the past year or so, and I had never really thought about it before. I am White, so I ticked the "White" box and submitted the survey. Later that evening, I heard on the news about another traditionally Jewish fraternity being vandalized on a college campus in the United States (Timm, 2015), the third similar incident in the previous six months. I began to think. I am Jewish, American, and have a light skin tone. I am not African American, Latino, or Native American, so I must be White. I mean, I have always thought of myself as being White due to the color of my skin. Right? Suddenly, a thought crossed my mind -- how can I possibly be White in American society if, as a Jew, my people are still being victimized and persecuted by those who are labeled as White? How can I be White if many White people in this country still dislike and distrust me due to my religious and cultural traditions? 
Furthermore, how do I navigate the notion of Whiteness in my own teaching of multicultural and social justice issues at the university level? All of these questions swirled around my mind as I wondered why, during my doctoral-level university courses in multiculturalism and social justice, Judaism and antisemitism were never discussed, not once, in my four years studying curriculum and instruction with a focus on critical pedagogies.

\section{Diversity and Multicultural Education}

In the new millennium, multicultural education and social justice courses have begun to make inroads in university teaching programs across the United States (Chou, 2007). James A. Banks (1992), a leader in the field of multicultural education, asserted that multicultural education was "essential in today's ethnically polarized and troubled world" because it attempted to "close the gap between the Western democratic ideals of equality and justice and societal practices that contradict those ideals, such as discrimination based on race, gender, and social class" (p. 32). While I agree adamantly with the necessity for diversity and multicultural education (DME), the simple fact is that Jewish people are not being given due diligence in the DME classroom in the United States. The lack of focus on Jews and Jewish issues (e.g., antisemitism) is evident in various ways, such as their absence in major diversity and multicultural texts used at the university level. No real discussion of Jews is present, in any capacity, in several prominent books in the field of multicultural education, such as Multicultural Education: Issues and Perspectives (9th ed.) by Banks and Banks (2016), Affirming Diversity: The Sociopolitical Context of Multicultural Education (6th ed.) by Nieto and Bode (2011), Rethinking Multicultural Education: Teaching for Racial and Cultural Justice (2nd ed.) by Au (2014), and Multicultural Education, Critical Pedagogy, and the Politics of Difference by Sleeter and McLaren (1995). In Teaching for Diversity and Social Justice by Adams, Bell, Goodman, and Joshi (2016), Jews are only discussed on a few occasions in one chapter titled "Religious Oppression" (pp. 255-297). As seen from several substantial academic texts, Jewish Americans are still under-represented, if represented at all, in multicultural education texts.

While many university programs in the United States focus on issues of racism, classism, sexism, and heterosexism, little, if anything, is presented about antisemitism or Jewish oppression (MacDonald-Dennis, 2006). Cohen, Harber, Jussim, and Bhasin (2009) assert that, "many major works on stereotypes, prejudice, and discrimination have paid relatively little attention to resurgent antiSemitism" (p. 290). While some texts do address the topic of religious oppression, the specific discussion of Jewish oppression and/or antisemitism is still often missing. It has been asserted by Altman, Inman, Fine, Ritter, and Howard (2010) that "Jewish oppression and multiculturalism do not fit into currently established analyses of racism and economic oppression (i.e., underrepresented minorities, people of color)" (p. 163). In U.S. society today, when one says the term "multicultural," it is often synonymous with "people of color" (Galchinsky, 1994). Since Jews in the United States are often seen as White (Altman et al., 2010; 
Greenberg, 2013, Singer, 2008) ${ }^{1}$, they do not fit into the category of multiculturalism. Even though it has been reported that acts of antisemitism are at their highest levels since WWII (Weinstein \& Jackson, 2010), addressing the discrimination of Jewish people is still absent from most multicultural and social justice university classrooms (Altman et al., 2010; Langman, 1995; MacDonaldDennis, 2006).

According to Schlosser (2006), "Judaism is a culture, a religion, an ethnicity, and a set of traditions that is embedded in Jewish people's expectations, belief systems, and family dynamics" (p. 424). Jewish people in the United States most often belong to one of three main groups: Orthodox, Conservative, or Reform Judaism, and each differs in both practice and philosophy (Levine-Rasky, 2008; Singer, 2008); therefore, American Jews are not a monolithic community (Bernstein, 2012). Jews, just like any other minority group, vary in social class, education, political affiliation, religious adherence, and so on. I do not argue that significant variations exist in Jewish identity; I simply attempt to situate Judaism and antisemitism in a multicultural context, which is often missing in DME education. In this article, I seek to answer several questions:

1. What is "Whiteness" in regard to Jewish Americans?

2. Why are Jews not often addressed in university multicultural and social justice course discussions?

3. How does a lack of presence in U.S. university DME courses affect how Jews view themselves and their place in U.S. society?

\section{Antisemitism Statistics}

In the United States today "there are about 4.2 million American adults who say they are Jewish by religion, representing 1.8 percent of the U.S. adult population" (Lipka, 2013, p. 1). Despite being such a small minority group, the most recent anti-religion hate crime statistics confirm that Jewish people continue to have the highest percentage of crimes committed against them in the United States (U.S. Department of Justice Federal Bureau of Investigation, 2016). Data show that, of the 1,163 victims of an anti-religion hate crime, $51 \%$ were Jewish (U.S. Department of Justice Federal Bureau of Investigation, 2016). For the sake of comparison, the next closest group experienced anti-Islamist (Muslim) bias, about $22 \%$. While any type of crime based upon one's religion is concerning (not to mention horrifying and infuriating), these statistics are meant to show the need for understanding and representation of Jewish people, not to minimalize the needs of the Muslim community in the United States.

Data show that 917 known hate groups exist across the United States today (e.g., neo-Nazis, White nationalists, Black separatists, Klansmen, neoConfederates, and skinheads). Most, if not all of those groups, hold virulent antisemitic beliefs (Southern Poverty Law Center, 2017). Recent data also show that incidents of antisemitism, including harassment and threats, vandalism, and 
physical assault, have risen $86 \%$ in the first quarter of 2017 alone in the United States (ADL, 2017). In particular, in the past year, U.S. college campuses "continued to be a hotbed for antisemitism: [there was a] 45 percent increase in antisemitism of all forms, especially harassments and insults" (Moshe Kantor Database, 2016, p. 6). It is apparent that, based on these numbers, antisemitism is still quite prevalent in the United States.

Around the world, statistics of antisemitic activity show varying trends. According to the Moshe Kantor Database (2016):

Antisemitic incidents and manifestations in 2016 reflect two parallel yet contradicting trends: one is the continuance of a notable decrease in the number of incidents, especially the violent ones, in most countries, mainly in several central ones, in which a large Jewish population resides. The other trend is the continuation of the widespread increase, sometimes dramatic, in verbal and visual antisemitism on social media and during demonstrations, in insults, harassments and threats hurled at people, that cannot be quantified: the internet constitutes originally a virtual reality, but has become today's reality and the main platform for the distribution of bigotry and hate, in abusive unleashed language. (p. 5)

Although incidents of violent antisemitism are on the decline around the world, attacks via the internet are thriving. Unfortunately, it is close to impossible to document the specific number of antisemitic messages sent via the web. This is a new age of antisemitic activity where antisemitism, like other forms of racism and discrimination, is hidden just out of view (Cohen et al., 2009; Weinstein \& Jackson, 2010). Due to these glaring statistics, it is essential that Jewish people are discussed in DME courses on university campuses across the United States.

\section{The Notion of "Whiteness" and White Identity}

To begin, it is important to note that "to write of whiteness of 'race' and to write of 'race' is to enter a conceptual and ethical quagmire" (Levine-Rasky, 2008, p. 52). Whiteness and one's place in it is a complicated, multifaceted concept based on identity, acculturation, power, and privilege (Giroux, 1997; Green, 2016; Levine-Rasky, 2008). That being said, in U.S. society "we have come to understand that a European, white-dominated system formulated who would be considered white, giving permission to some groups to move freely up and down the ladder of social hierarchy developed around race" (Beam, 2007, p. 210). For Jewish people in the United Sates, this has changed a great deal over time. According to Green (2016):

From the earliest days of the American republic, Jews were technically considered white, at least in a legal sense. Under the Naturalization Act of 1790 , they were considered among the 'free white persons' who could become citizens. Later laws limited the number of immigrants from certain countries, restrictions which were in part targeted at Jews. But unlike Asian 
and African immigrants in the late 19th century, Jews retained a claim to being 'Caucasian,' meaning they could win full citizenship status based on their putative race. (p. 3)

It was soon after WWII, during the 1940s and 1950s, when Jewish people began to gain access to many institutional privileges of being White in America and soon became one of the most upwardly mobile (economically) of all of the European ethnic groups in the United States (Brodkin, 2000). Post WWII, Jews were not really seen as a minority group in the United States by the larger society; they were simply seen as White (Singer, 2008).

According to Langman (1995), "[The notion] that Jews are White is relatively new and provides the irony that Jews, who have a long history of being oppressed by Whites as a non-White 'other,' are now grouped with the same Whites who have been their oppressors" (p. 4). Given this information, I believe that an important question to ask is whether it is possible for American Jews to truly be White if there are those in the United States (e.g., certain race-based hate groups) who think of Jews as being non-White. Singer (2008) also problematizes this concept when she states, "How can a society so concerned with promoting multiculturalism still not see us as a minority? I may be white, but I live in two worlds, and neither one totally accepts nor understands the other.... We remain a hidden minority amidst white privilege" (p. 51). Now, it is true that White Jewish people, unlike most people of color in the United States, often "pass" as being White by their looks alone (Freedman, 2005; Greenberg, 2013). This is based on having a lighter skin tone and facial features. ${ }^{2}$ As a result, they have the ability to reap many benefits of White privilege (Green, 2016; Langman, 1995; Maizels, 2011), such as the ability to obtain high-paying jobs, live free of police harassment, and move to whichever neighborhoods they choose. It has been asserted that being Jewish is really a form of invisible minority status due to the ability to blend in, or "pass" as White, within the predominant culture (Schlosser, Talleyrand, Lyons, \& Baker, 2007).

The question still remains whether Jewish people in the US are truly White. That is a complex question and difficult to answer. When Levine-Rasky (2008) contemplates the issue, she asserts, "Yes, sufficiently often in North America on the basis of 'race', but 'no' on the basis of the instability of this category. Are Jews privileged? Yes, sufficiently often in North America on the basis of social class, but 'no' on the basis of its social cost" (p. 53). Jews have benefitted and continue to benefit from White privilege in the United States, yet they are still often singled out for persecution and discrimination. In truth, being able to benefit from certain aspects of White privilege does not erase past and present acts of aggression and oppression of the Jewish peoples. In the United States today, White Jews still confront racist realties, such as vandalism of synagogues, gravesites, and community centers, as well as physical and online harassment and threats. Becoming accepted in U.S. society, in the form of White privilege, has also come at a great cost to the Jewish people.

Some theorists have asserted that there is a "second wave" of White identity studies (Jupp, Berry, \& Lensmire, 2016; Jupp \& Slattery, 2010; Jupp \& Slattery, 
2012), yet this new area of study is not likely to affect how Jews see themselves and others. Jupp and Slattery (2010) posit that:

Identifications, in superseding identities and identity formations, recognize that historical and social contexts structure and call identities into being.... Identifications are interactive narrative processes through which identities emerge within social and historical contexts; therefore, we read respondents' narratives vertically for change over time rather than horizontally as static 'types' or 'maps.' (p. 458)

For Jewish people, this reinforces the idea that identity can change over time, in terms of how they perceived themselves and are perceived as a group; this notion of Whiteness is not set in place for eternity. Lensmire et al. (2013) also discuss how the issue of Whiteness intersects with topics of gender, sexuality, or social class and how this changes over time. DiAngelo (2016) has asserted that "many Ashkenazic Jewish people don't identify as fully white because there are aspects of whiteness - for example, psychological freedom and freedom of movement that they don't completely enjoy" (p. 104). In other words, there are some privileges that White Jews are privy to, yet that does not mean that they receive all privileges of the White population in the United States.

It has also been recorded that, for over four millennia, Jews have been scorned, discriminated against, and persecuted all around the world. Jewish people have been hated for being a foreign, mongrel race, who have only been successful economically due to their conniving financial trickery and corrupt bargains (Freedman, 2005; Levine-Rasky, 2008). ${ }^{3}$ Jews have also been perceived as being dirty, swarthy, unattractive (having beady eyes and big noses), and even diseased (Gilman, 1994; Segal, 1999; Weinbaum, 1998). Additionally, and probably most importantly, Jews were accused of being the killers of Jesus Christ (Freedman, 2005; Gilman, 2003; Schlosser, 2006). Brodkin (2000) asserted that "whiteness is a state of privilege and belonging" (p. 182), explaining, "Race is not just a matter of skin pigmentation or ethnic background. It is determined by both individuals and their observers, and the boundaries of who's in or out of one group or another change constantly" (Green, 2016, p. 7). That being the case, another question arises: Due to the great distrust and disdain that many White people have had for the Jewish people over millennia, how did Jewish people ever become White? In other words, how did Jews become accepted and thriving members in U.S. society if they were of such low moral and ethical character at odds with the prevailing belief system of White America?

I will not present an exhaustive history of Jewish people in the United States in this piece, but it has been documented that classifications of Jewish people, depending on the specific time in American history, have oscillated greatly. Ultimately, "Jewish identity, or the way Jews understand themselves as a group, is complex and shifting, constituted by social and residential ties, friendships, community interests, a shared sense of history, and religious and cultural practices" (Greenberg, 2013, p. 35). History has shown that, in certain periods, White society has assigned Jewish people to the White race; other times, some type of off-White race (Brodkin, 2000). According to Brodkin: 
The Jews' unwhitening and whitening were not of their own making. Rather, the movements were effected by changes in national economic, institutional, and political practices, as well as by changes in scientific and public discourses about race in general and Jews in particular. (p. 175)

It was not until after WWII, and the atrocities of the holocaust in Europe (also referred to as the Shoah, in Hebrew), that Jews began to be considered White in the United States (Weinbaum, 1998). ${ }^{4}$ Lensmire et al. (2013) observe that "White privilege is not the cause of racial differentiation and structures; it is the effect of the socially, politically, and economically constructed system that we call race" ( $p$. 421). This changing of labels was primarily due to Jewish people's ability to integrate into American society by assimilating their language, culture, occupation, dress, and physical appearance (e.g., clothes and hair styles) (Gilman, 2003).

\section{Jewish Sense of Self}

Many Jewish people living in the United States today experience a difficult negotiation between being seen as White and being true to one's Jewishness, whether it be based on religion, cultural tradition, or family bloodline. Weinbaum (1998) has asserted that "Jews find that [they] occupy a liminal zone - [they] have consciousness of [themselves] as outsiders and experience being excluded by insiders" (p. 184). For many American Jews, there is a balancing act attempting to negotiate two different, and often tension-filled, worlds. How Jews see themselves racially can be quite complicated (DiAngelo, 2016). As stated by Levine-Rasky (2008), "A poignant tension arises in confronting the attained status of the Jews. Jews are both Whites and racialized, both privileged and impaired. This ambiguity creates fear" (p. 61).

According to literature in the areas of counseling and psychology, this is a potential consequence of internalized racial oppression by the White majority in this country. Pyke (2010) has asserted that:

internalized White racism...emphasizes the psychic costs of internalized racial oppression defined as the individual inculcation of the racist stereotypes, values, images, and ideologies perpetuated by the White dominant society about one's racial group, leading to feelings of self-doubt, disgust, and disrespect for one's race and/or oneself. (p. 553)

These feelings of insecurity due to prejudice and discrimination are also referred to as "internalized antisemitism." Schlosser, Ali, Ackerman, and Dewey (2009) define internalized antisemitism as "the passive and/or active concealment of one's Jewish identity and feelings of self-hatred" (p. 56). These feelings have led many American Jews to hide amongst their goyische (non-Jewish) neighbors. Gilman (1994) has posited that American Jews have internalized the various negative images of being Jewish (e.g., as pushy, penny-pinching cheats) and, by doing so, they have internalized the desire to maintain their own Jewish identity while trying 
to not actually be seen as a Jew, which would be much more widely acceptable than being seen as "too Jewish."

Not looking Jewish was, and is to this day, a concern in the American Jewish community. Many American Jews keep their identity hidden for fear of what might eventually come if they are found out to be a Jew (Altman et al., 2010), so they often go to great lengths to avoid bringing attention to their Jewishness, even to the point of having cosmetic surgery. This concern of looking "too Jewish" is reflected in the desire for rhinoplasty (Gilman, 1994), for example. As another example, proper grooming of a White Jewish person's oft curly hair, more recently referred to as the "Jew-fro" (Gilman, 2003), is also necessary in order to pass as White in the United States. Many Jews undergo this type of physical transformation just so that they can pass as being White in America and thereby being spared potential harassment and discrimination.

American Jews often see themselves, not only as a minority group, but as those whose existence is constantly in question (Langman, 1995). Four thousand years of persecution has created a sense of internalized fear, one which "leads many Jews to keep a low profile and not call attention to themselves as Jews. Historically, being Jewish has been dangerous, and that legacy is deeply imbedded in the consciousness of Jews" (Langman, 1995, p. 6). This fear is understandable since Jews have been persecuted in almost every nation on earth and have been continually seen as the enemy (DiAngelo, 2016). After the U.S. presidential election, this fear has not changed. Currently in the United States, "Trump's election has convinced some Jews that they remain in the same position as they have throughout history: perpetually set apart from other groups through their Jewishness, and thus left vulnerable" (Green, 2016, p. 3). American Jews are perceived as the proverbial wolves in sheep's clothing. As long as they are seen as one of the herd, they are safe, but as soon as they are exposed to be who they truly are (or perceived to be by non-Jews), then they open themselves up for potential violence and discrimination.

In large part due to the financial gains of many American Jews in the last half century, as well as their blending into all aspects of White society, Jews are often seen as a successful, or "model," minority (Freedman, 2005; Gilman, 2003). A model minority is seen by society as being economically successful, high achieving (academically), and causing few problems for the mainstream culture (Freedman, 2005; Yu, 2006). The perception of Jewish Americans as a model minority is erroneous and misleading (as is the case for all peoples considered to be model minorities). Take economic success, for example. Despite what many Americans might think, the simple fact is that many Jews live in poverty in the United States. For instance, a special report on poverty by the United Jewish Appeal (UJA)-Federation of New York found that 565,000 New York Jews (about $20 \%$ ) live in households near or below the federal poverty line (Rapfogel, 2013). As discussed earlier, the stereotype of the wealthy, financially savvy Jew is just that, a stereotype that was practically forced upon them by the Roman Catholic Church (Muller, 2010). 
It has also been posited that Jewish Americans have made great gains in the areas of medicine, law, and politics in recent decades (King \& Weiner, 2007). While some believe that Jews are one of the most privileged groups in the United States and are even seen as "elite" (Cannon, 2014) due to their mainstream impact on the arts and sciences (Alba, 2006), that does not mean full societal acceptance. Becoming financially stable and passing for White in this country does not equate to a positive perception of Jewish beliefs and customs. According to Rubin (2013):

Just because many people love the music of Neil Diamond, reruns of Seinfeld, and watching Adam Sandler films does not, in any way, mean actual societal acceptance of Jewish people. It is situational and hollow, an acceptance based on tolerance in small doses and in confined, predetermined spaces. (p. 215)

Despite the commercial success of particular American Jews in the music and entertainment industry (e.g., Idina Menzel or Ben Stiller), Jews, as a whole, are still discriminated against in the United States and judged as being "less than."

Ultimately, being perceived as Jewish can have a negative impact on how one sees oneself in U.S. society. This was evident when, in March 2015, a gubernatorial candidate in Missouri committed suicide after rumors began to spread that he was Jewish (Bever, 2015). While the exact reason why this person ended his life might never be known, the smear campaign about him being Jewish appears to be a primary cause of his killing himself. This particular instance is indicative of the existing negative connotation of being Jewish in parts of the United States. The fact that some Jewish people have accomplished economic success and mainstream popularity does not mean that Jews are truly respected or accepted as a people. Being labeled as a Jewish person brings its own weight and meaning in U.S. society, and for some it is hurtful and damaging.

\section{Exclusion from Multicultural and Social Justice Discourse}

The study of antisemitism, or the discrimination against Jewish people, is not often discussed in the multicultural and social justice university classroom (MacDonald-Dennis, 2006). This is due to many reasons, such as the belief that American Jews are members of a religion but not a culture, they have assimilated completely into White culture, they are successful economically, and they live free from oppression (Langman, 1995; MacDonald-Dennis, 2006; Schlosser et al., 2009). Due to these and other falsehoods believed about US Jews, it is imperative that university students be provided the opportunity to analyze critically the stereotypes that are attributed to Jewish people (MacDonald-Dennis, 2006).

Not being discussed in the DME classroom tells Jewish students, in a subtle or not so subtle way, that their experiences have no real importance and that they just do not matter (MacDonald-Dennis, 2006). In addition, non-Jews are also given the message that Jews are not in need of racial/ethnic exploration and discussion as are other discriminated groups in American society (e.g., people of color, 
members of the GLBTQ community) and do not deserve recognition as victims of discrimination and persecution. According to Giroux (2006):

The university should be a principal site where dialogue, negotiation, mutual understanding, and respect provide the knowledge and experience for students to develop a shared space for affirming differences while simultaneously learning those shared values necessary for an inclusive democratic society. (p. 190)

Universities in the United States (and around the world) can be the ideal environment to discuss issues involving all oppressed groups of people, including Jews. It is critical that they are also invited into the dialogue.

While the notion of Whiteness is often associated with innocence and purity by the White majority, it actually stands for domination, oppression, and privilege (Giroux, 1997). Jews have been alienated and marginalized for thousands of years (Alhadeff, 2014) and, based on current trends, racism and discrimination of Jews in the United States, and around the globe, continue to increase. American Jews comprise a very small percentage of this country's population (about $2 \%$ ), but they have a very distinct culture and language (i.e., Hebrew and/or Yiddish), as well as traditions, which differ from the majority in the United States. According to Grant and Zwier (2011), "Policies and practices that do not take into account students' intertwining identity axes risk reproducing patterns of privilege and oppression, perpetuating stereotypes, and failing at...supporting all students' learning across a holistic range of academic, personal, and justice-oriented outcomes" (p. 187). In other words, properly introducing antisemitism into university classroom discussions of multiculturalism and social justice can help change the tide of discrimination and hatred against American Jews for this, and future, generations. Identifying as an American Jew is quite important in modern society, for it determines how one sees oneself, the society in which one lives, and one's ability to negotiate both worlds (White and Jewish). Langman (1995) asserts that, since Jews are not often associated with being a minority group in the United States, "it is easy for them to doubt the validity of their experiences as members of a minority" (p. 5). Addressing Jews and Jewish issues in the university classroom can impact positively both Jews and non-Jews alike.

It is quite unfortunate that, in this day and age, "many American Jews will have a personal experience with antisemitism at some point in their lives; nearly all Jews are impacted by acts of antisemitism vicariously" (Schlosser, 2006, p. 433). In DME courses, there is a need for open and honest Jewish representation and discussion. In the university classroom, "everyone's perspective is not equally valid when some are uninformed, unexamined, or uphold existing power inequities" (Sensoy \& DiAngelo, 2014, p. 4); therefore, issues of antisemitism cannot be fleshed out without proper discussion and critical analysis in the classroom. 


\section{Conclusion}

Antisemitism is alive and well around the globe. In the United States in particular, acts of antisemitism have exploded since the election of a new president in 2016 (ADL, 2017), and this trend has also continued on university campuses (Moshe Kantor Database, 2016). An effective way to help break down stereotypes and misunderstandings of Jewish people is by creating a dialogue about Jewish issues in the DME university classroom. According to Singer (2008), understanding of Jewish issues in education is important for two reasons:

The first is lack of knowledge in the general population and the permeation of this deficiency. The second is misinformation which may be disseminated due to lack of knowledge and poor choice of resources. The biggest problem comes from people not even knowing they don't know. (p. 50)

It appears that, at least in the United States, the "fact that Jews are a minority is not widely acknowledged. Or, if they are acknowledged as a numerical minority, they are relegated to a status of somehow 'not counting' as a minority" (Langman, 1995 , p. 2). Unfortunately, due to many reasons, such as bigotry, stereotyping, and internalized racism, this view is held by both Jews and non-Jews alike in the United States. It is for these reasons that American Jews need to be recognized as their own unique group that continues to battle various forms of discrimination and oppression (MacDonald-Dennis, 2006). A positive and productive way to achieve that goal is to bring the study of antisemitism into the multicultural and social justice university classroom.

\section{Notes}

1. It must be noted that there are a great number of Jews, both in the United States and around the world, who are not seen as White, such as Latino/a Jews in the United States, the Beta Israel from Ethiopia, and the Kaifeng Jews of China (Levine-Rasky, 2008). The focus of this piece rests solely on those Jews who are light-skinned and thereby assumed to be White.

2. According to Schlosser (2006), "There are three main lineages for Jewish People: Ashkenazim, Sephardim, and Mizrachim. The Ashkenazim are Jews who trace their historical lineage to Eastern Europe; they are, quite often, the face of American Jewry" (p. 426).

3. In Europe during the 12th century, Jews only became involved in money lending because Christians considered the practice to be necessary yet inherently evil. Since Jews were believed to be damned already due to their rejection of Christ, this was an appropriate job for them (Muller, 2010). 
4. For a more expansive, historical analysis of Jewish people and the notion of Whiteness, I suggest reading Brodkin (2000), How Jews Became White Folks and What That Says About Race in America.

\section{References}

Adams, M., Bell, A., Goodman, D. J., \& Joshi, K. Y. (Eds.). (2016). Teaching for diversity and social justice. New York, NY: Routledge.

Alba, R. (2006). On the sociological significance on American Jewish experience: Boundary blurring, assimilation, and pluralism. Sociology of Religion, 67(4), 347-358.

Alhadeff, C. J. (2014). Viscous expectations: Justice, vulnerability, the ob-scene. New York, NY: Atropos Press.

Altman, A. N., Inman, A. G., Fine, S. G., Ritter, H. A., \& Howard, E. E. (2010). Exploration of Jewish ethnic identity. Journal of Counseling \& Development, 88(2), 163-173.

Anti-Defamation League. (2017). U.S. anti-Semitic incidents spike 86 percent so far in 2017 after surging last year, ADL Finds. Retrieved from https://www.adl.org/news/press-releases/us-anti-semitic-incidents-spike86-percent-so-far-in-2017

Au, W. (Ed.). (2014). Rethinking multicultural education: Teaching for racial and cultural justice. Milwaukee, WI: Rethinking Schools.

Banks, J. A., \& Banks, C. A. (2016). Multicultural education: Issues and perspectives (9th ed.). Hoboken, NJ: Wiley.

Banks, J. A. (1992). Multicultural education: For freedom's sake. Educational Leadership, 49(4), 32-36.

Beam, C. B. (2007). A conversation on the semantic pedagogy of "Whiteness." ETC: A Review of General Semantics, 64(3), 209-217.

Bernstein, D. (2012, July 30). Academic tradition demands more evenhanded treatment of Israel. The Chronicle of Higher Education, 58(42). Retrieved from http://chronicle.com/article/Academic-Tradition-Demands/133183/

Bever, L. (2015, March 6). Just before suicide, Missouri politician fretted about rumors he was Jewish. The Washington Post. Retrieved from http://www.washingtonpost.com/news/morning-mix/wp/2015/03/06/thetragic-last-moments-before-a-missouri-politician-took-his-life-upset-aboutrumors-that-he-was-jewish/

Brodkin, K. (2000). How Jews became white folks and what that says about race in America. Piscataway, NJ: Rutgers University Press. 
Cannon, B. (2014, December 4). Jews, white privilege and the fight against racism in America. Retrieved from http://www.haaretz.com/jewish-world/ thejewish-thinker/1.629888

Chou, H. (2007). Multicultural teacher education: Toward a culturally responsible pedagogy. Essays in Education, 21, 139-162.

Cohen, F., Harber, K. D., Jussim, L., \& Bhasin, G. (2009). Modern anti-Semitism and anti-Israeli attitudes. Journal of Personality and Social Psychology, 97(2), 290-306.

DiAngelo, R. (2016). What does it mean to be white? Developing white racial literacy (Rev. ed.). New York, NY: Peter Lang.

Freedman, J. (2005). Transgressions of a model minority. Shofar: An Interdisciplinary Journal of Jewish Studies, 23(4), 69-97.

Galchinsky, M. (1994). Glimpsing golus in the golden land: Jews and multiculturalism in America. Judaism: A Quarterly Journal of Jewish Life, 43(4), 360-368.

Gilman, S. L. (1994). The Jewish nose: Are Jews white? Or, the history of the nose job. In L. J. Silberstein \& R. L. Cohn (Eds.), The other in Jewish thought and history: Constructions of Jewish culture and identity (pp. 364-401). New York, NY: New York University Press.

Gilman, S. L. (2003). "We're not Jews": Imagining Jewish history and Jewish bodies in contemporary multicultural literature. Modern Judaism, 23(2), 126-155.

Giroux, H. A. (1997). White squall: Resistance and the pedagogy of whiteness. Cultural Studies, 11(3), 376-389.

Giroux, H. A. (2006). Reading Hurricane Katrina: Race, class, and the biopolitics of disposability. College Literature, 33(3), 171-196.

Grant, C. A., \& Zwier, E. (2011). Intersectionality and student outcomes: Sharpening the struggle against racism, sexism, classism, ableism, heterosexism, nationalism, and linguistic, religious, and geographical discrimination in teaching and learning. Multicultural Perspectives, 13(4), 181-188.

Green, E. (2016, December 5). Are Jews White? The Atlantic. Retrieved from https://www.theatlantic.com/politics/archive/2016/12/are-jews-white/ 509453/

Greenberg, C. (2013). "I'm not White - I'm Jewish": The racial politics of American Jews. In E. Sicher (Ed.), Race, color, identity: Rethinking discourses about "Jews" in the twenty-first century (pp. 35-55). New York, NY: Berghahn Books.

Jupp, J. C., Berry, T. R., \& Lensmire, T. J. (2016). Second-wave White teacher identity studies. Review of Educational Research, 86(4), 1151-1191. 
Jupp, J. C., \& Slattery, G. P. Jr. (2010). Committed White male teachers and identifications: Toward creative identifications and a "second wave" of White identity studies. Curriculum Inquiry, 40(3), 454-474.

Jupp, J. C., \& Slattery, G. P., Jr. (2012). "Becoming" teachers of inner-city students: Identification creativity and curriculum wisdom of committed White male teachers. Urban Education, 47(1), 280-311.

King, R. D., \& Weiner, M. F. (2007). Group position, collective threat, and American antisemitism. Social Problems, 54(1), 47-77.

Langman, P. F. (1995). Including Jews in multiculturalism. Journal of Multicultural Counseling \& Development, 23(4), 222-236.

Lensmire, T. J., McManimon, S. K., Tierney, J. D., Lee-Nichols, M. E., Casey, Z. A., Lensmire, A, \& Davis, B. M. (2013). Mclntosh as synecdoche: How teacher education's focus on White privilege undermines antiracism. Harvard Educational Review, 83(3), 410-431.

Levine-Rasky, C. (2008). White privilege: Jewish women's writing and the instability of categories. Journal of Modern Jewish Studies, 7(1), 51-66.

Lipka, M. (2013, October 2). Fact tank - Our lives in numbers: How many Jews are there in the United States? Pew Research Center. Retrieved from http://www.pewresearch.org/fact-tank/2013/10/02/how-many-jews-arethere-in-the-united-states/

MacDonald-Dennis, C. (2006). Understanding antisemitism and its impact: A new framework for conceptualizing Jewish identity. Equity \& Excellence in Education, 39(3), 267-278.

Maizels, L. (2011). On whiteness and the Jews. Journal for the Study of Antisemitism, 3(2), 463-488.

Moshe Kantor Database for the Study of Contemporary Antisemitism and Racism. (2016). Antisemitism worldwide 2016: General analysis draft. Retrieved from http://kantorcenter.tau.ac.il/

Muller, J. Z. (2010). Capitalism and the Jews. Princeton, NJ: Princeton University Press.

Nieto, S., \& Bode, P. (2011). Affirming diversity: The sociopolitical context of multicultural education ( $6^{\text {th }}$ ed.). Boston, MA: Pearson Education.

Pyke, K. D. (2010). What is internalized racial oppression and why don't we study it? Acknowledging racism's hidden injuries. Sociological Perspectives, 53(4), 551-572.

Rapfogel, W. E. (2013, July 10). The ignored Jewish poor: Study finds half a million American Jews living in poverty. The Jewish Daily Forward. Retrieved from http://forward.com/articles/179934/the-ignored-jewish-poor/?p=all

Rubin, D. I. (2013). Still wandering: The exclusion of Jews from issues of social justice and multicultural thought. Multicultural Perspectives, 15(4), 213219. 
Schlosser, L. Z. (2006). Affirmative psychotherapy for American Jews. Psychotherapy: Theory, Research, Practice, Training, 43(4), 424-435.

Schlosser, L. Z., Ali, S. R., Ackerman, S. R., \& Dewey, J. J. H. (2009). Religion, ethnicity, culture, way of life: Jews, Muslims, and multicultural counseling. Counseling and Values, 54(1), 48-64.

Schlosser, L. Z., Talleyrand, R. M., Lyons, H. Z., \& Baker, L. M. (2007). Racism, antisemitism, and the schism between Blacks and Jews in the United States: A pilot intergroup encounter program. Journal of Multicultural Counseling \& Development, 35(2), 116-128.

Segal, D. A. (1999). Can you tell a Jew when you see one? Or thoughts on meeting Barbra/Barbie at the museum. Judaism, 48(2), 234-241.

Sensoy, Ö, \& DiAngelo, R. (2014). Respect differences? Challenging the common guidelines in social justice education. Democracy \& Education, 22(2), 1-10.

Singer, J. M. (2008). A hidden minority amidst White privilege. Multicultural Perspectives, 10(1), 47-51.

Sleeter, C. E., \& McLaren, P. L. (Eds.). (1995). Multicultural education, critical pedagogy, and the politics of difference. Albany, NY: State University of New York Press.

Southern Poverty Law Center. (2017). Hate map: Active U.S. hate groups. Retrieved from https://www.splcenter.org/hate-map

Timm, J. C. (2015, March 18). Jewish fraternity vandalized with swastikas. Retrieved from http://www.msnbc.com/msnbc/vanderbilt-university-jewishfraternity-vandalized-swastikas

U.S. Department of Justice Federal Bureau of Investigation. (2016). 2015 Hate crime statistics. Retrieved from https://ucr.fbi.gov/hate-crime/2015/topicpages/incidentsandoffenses_final

Weinbaum, B. (1998). How the job market, antisemitism and affirmative action intersect: A glimpse in one life. NWSA Journal, 10(3), 183-191.

Weinstein, L., \& Jackson, C. (2010). College student antisemitism and anti-Israeli sentiment. College Student Journal, 44(2), 565-567.

$\mathrm{Yu}, \mathrm{T}$. (2006). Challenging the politics of the "model minority" stereotype: A case for educational equality. Equity \& Excellence in Education, 39(4), 325-333.

\section{Author Contact}

Daniel lan Rubin: drubin@jsu.edu

Jacksonville State University: 700 Pelham Rd N, Jacksonville, AL 36265 